\title{
MODELLING THE SPREAD OF RABIES IN UKRAINE
}

\author{
I. F. MAKOVSKA, PhD student ${ }^{1}$, Department of Epizootology, \\ Microbiology and Virology \\ https://orcid.org/0000-0001-9299-6682 \\ National University of Life and Environmental Sciences of Ukraine, Kyiv, \\ Ukraine \\ E-mail: iryna.makovska@nubip.edu.ua
}

\begin{abstract}
Due to the concern for animal and human health, efforts to develop mathematical and computational models for predicting the spatial and temporal dynamics of infectious diseases, including rabies, are constantly increasing. Therefore, our goal was to model the dynamics of the spread of rabies by foxes, dogs, and cats on the territory of Vinnytsia Oblast in the period from 2012 to 2018. To study and analyse the dynamic spread of rabies in time and space, an information-analytical technology was developed, which is based on retrospective data from registered cases of rabies. The rabies transmission parameter was determined using official epizootological data from the regional oblast veterinary laboratory and the regional department of the State Service of Ukraine On Food Safety and Consumer Protection. It was found that rabies spread the most among dogs and cats at a distance of up to $50 \mathrm{~km}$ in the winter (26.45\%), from 50 to $100 \mathrm{~km}$ - in the autumn (40.33\%), over $100 \mathrm{~km}$ - in the summer (49.84\%). In general, domestic carnivores were sources of rabies within a radius of $50 \mathrm{~km}$ in only $16.98 \%$ of cases, and within a radius of $100 \mathrm{~km}$ - in 55.95\% of cases. Foxes were sources of rabies within a radius of $50 \mathrm{~km}$ in only $24.33 \%$ of cases and within a radius of $100 \mathrm{~km}$ in $58.54 \%$ of cases. At the same time, the highest spread of rabies among the foxes at a distance of up to $50 \mathrm{~km}$ was observed in the spring (31.01\%), from 50 to $100 \mathrm{~km}$ - in the winter (43.67\%), and over $100 \mathrm{~km}$ - in the summer (48.38\%). The new data will be useful in planning and carrying out preventive antirabies measures. In the future, it is planned to conduct the modelling in terms of all regions and create forecasts for the spread of rabies on the territory of Ukraine.
\end{abstract}

Keywords: animal rabies, rabies distribution modelling, foxes, domestic carnivores, information-analytical technology

\section{Introduction}

Rabies infections are the cause of over $99 \%$ of all human rabies deaths, and therefore pose a serious threat to public health worldwide. Rabies viruses are transmitted to a wide range of globally distributed mammals, but only some species are able to be a reservoir. The twentieth century was significant

${ }^{1}$ Scientific supervisor - Doctor of Veterinary Sciences, Professor V. V. Nedosekov 
in the eradication of rabies due to effective attempts to eradicate rabies in the wildlife (Robardet et al., 2019) as well as by eliminating rabies from a number of European countries through strict sanitary measures (elimination of stray dogs, destruction of suspected animals, requirements for wearing muzzles on dogs, tracking the movement of rabid dogs and their contacts, restriction of movement and quarantine) (Cliquet et al., 2014; Müller \& Freuling, 2020). Therefore, the spread of rabies by reservoir species is a unique problem. Thus, mathematical and simulation models are useful tools to provide an understanding of the most effective rabies control strategies (Elmore et al., 2017; Rattanavipapong et al., 2019).

\section{Analysis of recent researches and publications}

Modelling provides an inexpensive way of studying the main parameters of wildlife rabies transmission, rabies management economics, its prevention and control (Sterner \& Smith, 2006). Many existing models that study the spread of rabies virus in Europe are associated with the appearance of rabies in one species, namely the red fox (Borchering et al., 2012). However, in Eastern Europe, especially in Ukraine, rabies continues to spread equally through foxes and domestic carnivores (Makovska et al., 2020). As reported by Drozhzhe (2015), over the past decade, our country, together with neighbouring countries such as the Russian Federation, Republic of Belarus, and Romania, has formed the epicentre of rabies, which accounted for up to $90 \%$ of all European countries.

In addition, Ukraine is the only country in Europe where rabies is spread even more through domestic carnivores than through foxes (Tkachenko et al.,
2014; Yarchuk et al., 2015; Golik et al., 2018). This epizootic situation is provoked on the one hand by a large number of homeless and stray dogs and cats, which move freely in all regions, transporting the causative agent of rabies and exacerbating the epizootic and epidemic situation and causing economic damage (Gulyukin et al., 2016; Kurtyak, 2017). On the other hand, the reason for the high incidence of rabies among domestic carnivores is the low vaccination rate (Achilov \& Nedosekov, 2013; Polupan et al., 2019). Because unvaccinated and stray animals are currently potential carriers of the rabies virus, they exacerbate an epizootic situation of an anthropological nature ("urban") (Rebenko et al., 2019).

According to Levkivsky et al. (2016), there is a relationship between the rabies incidence in foxes and stray cats. Because cats often come into contact with foxes during hunting, they become infected and transmit virulent strains of the rabies virus to other domestic carnivores and farm animals. This is facilitated by both the biological characteristics of animals and the intervention of human agricultural activities, which leads to the synantropization of wild animals and the savagery of domestic animals (Perotskaya, 2011). And, if the situation with wild animals is more controlled, then with domestic animals, and even more with stray and homeless animals in cities, the situation is the most unstable, uncontrolled, and threatening, both for humans and animals (Rebenko et al., 2019).

During the geographic information systems analysis for 2018 in all regions of Ukraine, it was found that cases of rabies in domestic carnivores were registered throughout the country with the most concentrated in the east and centre, while for foxes the most affected ar- 
eas by rabies were the territories in the west of Ukraine. In general, most cases of rabies were registered in Vinnytsia Oblast. On the one hand, it is the result of a large number of foxes and domestic carnivores, but on the other hand, it is the result of quality monitoring in this area. Also, it was found that during 2018 , cases of rabies in foxes registered the most in the first and fourth quarters, and in domestic carnivores mainly in the first quarter (Makovska, 2020).

In most cases, the transmission of the pathogen is mainly a localized process that occurs between animals with the most intense contact, provided that they are in one place. In this case, the movement of animals between settlements contributes to the geographical spread of infectious diseases. Given the limited knowledge about the patterns of animals' movement and their interspecific interaction, it is usually impractical to model each animal within a population.

Therefore, today, the analysis of the spread of rabies in space is possible with the use of appropriate information and analytical technology (Dzyublyk et al., 2017).

Purpose. Thus, the purpose of this study was to model the dynamics of the spread of rabies in areas with the highest concentration of registered rabies cases in the period from 2012 to 2018 .

\section{Materials and methods of research}

Approximation of percentage values of the dynamics of rabies spread was carried out for the period from 2012 to 2018, taking into account the full set of data collected from all regions of Ukraine. The main parameter of the model - the parameter of rabies transmission, was determined using official epidemiological data from regional lab- oratories of veterinary medicine and regional departments of the State Service of Ukraine On Food Safety and Consumer Protection.

The development of a qualitative prognostic model for the spread of rabies among domestic and wild animals is impossible today due to the incomplete or contradictory retrospective data on the prevalence of rabies. Accordingly, it is possible to build a concept of information and analytical technology aimed at analysing and summarizing existing data in order to study trends and make appropriate management decisions based on them.

To study and analyse the dynamic spread of rabies in time and space, information and analytical technology was developed, which is based on retrospective data on the recording of rabies cases in certain regions.

Algorithm of work of the developed information-analytical technology:

1. Filter available data according to specified criteria (such as region or species).

2. Clustering of filtered data by time periods in order to obtain data on the area of infection for a certain time period.

3. Sort clusters by time from the first to the last.

4. Determination of the centres of the regions as the average value of the cluster points.

5. Comparison of the obtained clusters with neighbouring ones to obtain data on the distance to which the region of infection has moved. The comparison is made using the geographical coordinates of the points of infection detection.

6. Construction of a discrete distribution of distances for each pair of comparable clusters.

By analysing the obtained discrete distributions of distances over a time pe- 
riod, it is possible to determine trends in the distance to which the infection zone is shifted, and based on the analysis of cluster centre displacement, trends in the direction of the infection zone might be determined (Fig. 1).

The set of analysed rabies cases is single-layered, but there are many complex real-world systems that might be represented as several layers of such separate sets. Most complex physical, social, engineering, information, and biological systems include several subsystems and levels of communication, and they are often open, meaningful, oriented, multilevel, multicomponent, rebuilt systems of systems, and located in unstable and changing conditions.

The following indicators: the interval duration of one month and the distance of $20 \mathrm{~km}, 50 \mathrm{~km}$, and $100 \mathrm{~km}$ were used for the analysis. Data were entered separately for each rabies case in the format of the region, district, city or town, animal species, date of diagnosis confirmation, and geographical coordinates of latitude and longitude.

The diagram was built in draw.io (https://app.diagrams.net/).

The limitation of the research was the limited method for modelling in areas with a small number of cases, as a result of

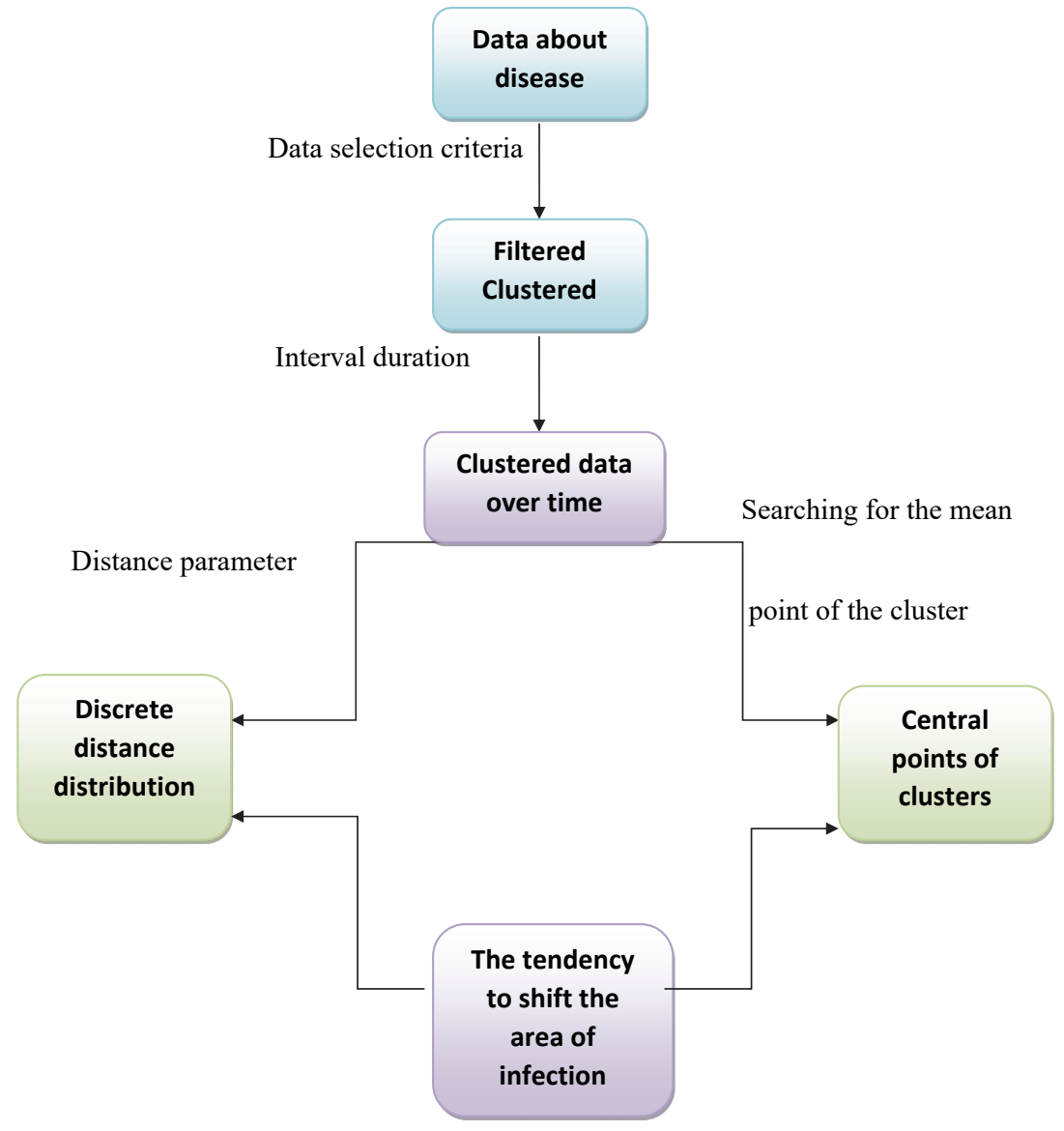

Fig. 1. Algorithm of actions of the developed information-analytical technology 


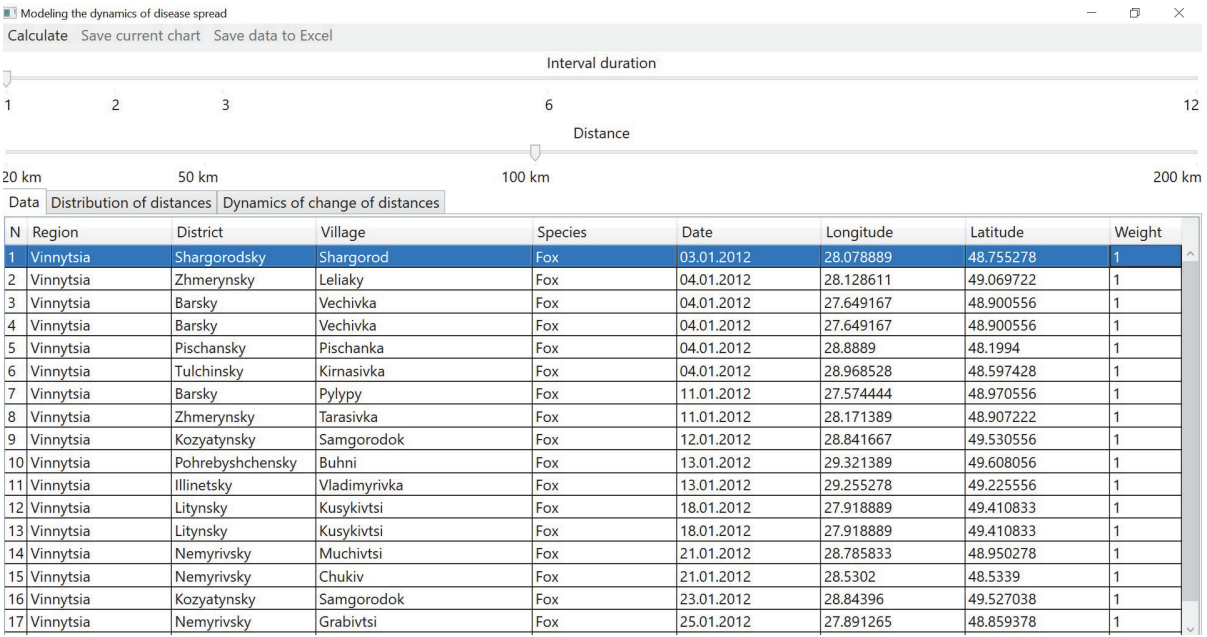

Fig. 2. Sample data on rabies cases among foxes for the 7-year period (2012-2018) in Vinnytsia Oblast

which the results of modelling in areas with the highest concentration of rabies cases were taken into account, the epicentre of which in recent years is Vinnytsia Oblast. Thus, we conducted modelling with data from all regions of Ukraine, but this paper presents the results on the example of Vinnytsia Oblast. For analysis, the developed system included information from the national database created by us, which was adapted for the modelling (Fig. 2).

\section{Results of the research and their discussion}

These results carry the greatest prognostic information about the peculiarities of the epizootic process of rabies. Modelling the dynamics of rabies in Ukraine differs as in territorial features as in species and season. Thus, we found that the disease spread up to $250 \mathrm{~km}$ per month within the region.

In general, the distance of distribution of rabies depended on season and species of animals. Firstly, we conducted modelling for 7 years. The results of modelling the spread of rabies with fixed intervals of up to $20 \mathrm{~km}$ and the interval duration of one month on the example of Vinnytsia Oblast are presented in Figure 3.

As we can see from this graph, the movement of rabies in foxes, dogs and cats has a wavy dynamics and is repeated every year with varying intensity. In summary, animals transmitted rabies over short distances in 10-40\% of cases. Distribution of rabies among species has shown that wild animals transmit the disease mainly over longer distances, which agrees with the available literature data.

Besides this, we conducted modelling of the dynamics of distance change at a fixed distance of up to $100 \mathrm{~km}$ and the interval duration of one month, which is presented in Figure 4.

These curves show the peaks of spread over long and short distances within each month. Among foxes the reduction of all peaks for the period from August 2015 to August 2016 is significant. This can be explained by changes in the number of foxes and the presence of a forage bases in this period. 


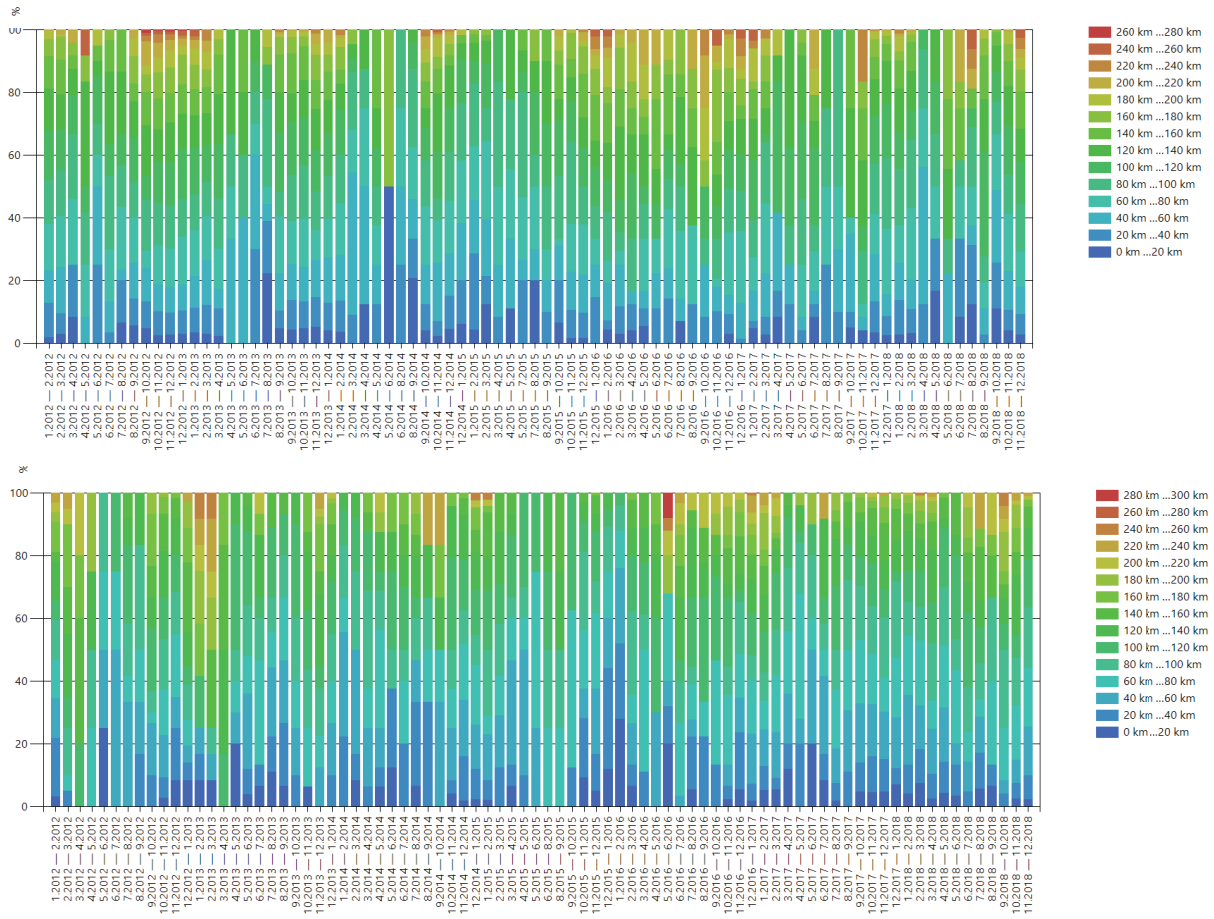

Fig. 3. Dynamics of distribution of rabies for the period from 2012 to 2018 on the territory of Vinnytsia Oblast (A - among foxes, B - among domestic carnivores)

For a more detailed study, we set aside one year and determined the distribution of rabies separately for foxes and domestic carnivores (Fig. 5).

These curves show sharp changes in the dynamics of rabies spread among foxes, and smoother for cats and dogs. This is due to the possibility of domestic carnivores being more attached to one habitat (Rebenko et al., 2019).

In addition, the longest periods of movement of rabid foxes were registered from July to August and from November to December in 2018. And among domestic carnivores, there is a clear visual rise of long-distance movements in the summer-autumn period and a decline in the winter-spring period.
Based on the results presented in the graphs, we determined the percentage of the dispersion of rabies, which is presented in Table 1.

To build this model, 95 confirmed cases of rabies among dogs and cats (domestic and stray) were studied. From the results presented in the graph and in Table 1 , we can see that the dynamics of the distribution of cases differed significantly depending on seasonality. Thus, we found that rabies spread the most at a distance of up to $50 \mathrm{~km}$ in the winter (26.45\%) compared to other months, at a distance from 50 to $100 \mathrm{~km}$ - in the autumn (40.33\%), and at a distance of more than $100 \mathrm{~km}$ - in the summer (49.84\%).

In general, domestic carnivores were sources of rabies within a radius of $50 \mathrm{~km}$ 


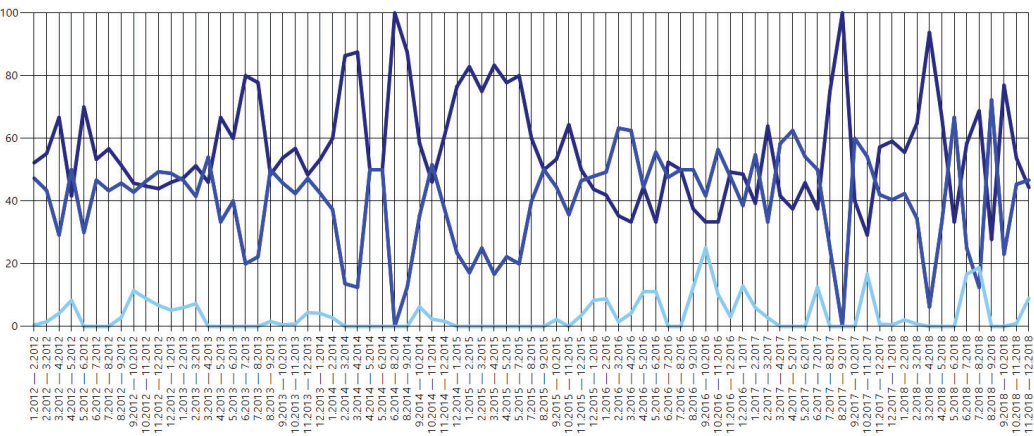

10

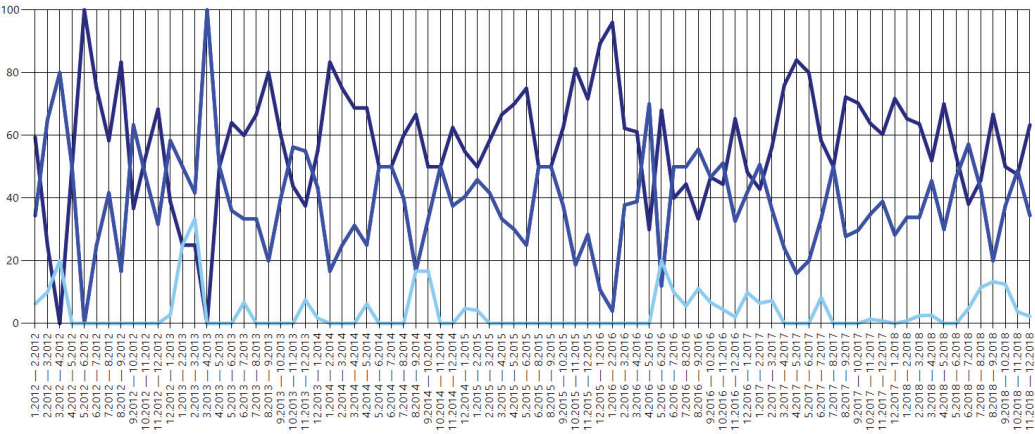

Fig. 4. Dynamics of distance change of rabies cases for the period from 2012 to 2018 on the territory of Vinnytsia Oblast with the fixed distance of up to $100 \mathbf{~ k m ~ ( A ~ - ~ a m o n g ~ f o x e s , ~ B ~ - ~ a m o n g ~ d o m e s t i c ~ c a r n i v o r e s ) ~}$

in only $16.98 \%$ of cases, and within a radius of $100 \mathrm{~km}-$ in $55.95 \%$ of cases.

Although this issue has not been studied in Ukraine today, there is an opinion in rabiology that a certain species of animals can carry the disease to a specific distance. As reported by Shcherbak (1982), the concept of ecological and anthropological limited borders of the spread of the disease means the migratory resources of animals, namely: wolf - up to $150 \mathrm{~km}$, fox $-10-15 \mathrm{~km}, \operatorname{dog}-5 \mathrm{~km}$, marten $-3 \mathrm{~km}$. That is the distance within which one infected animal can transmit the virus to another animal or human.

In our study, we found that domestic carnivores can carry the rabies virus over long distances (up to $100 \mathrm{~km}$ ) during the month.
This could be explained by the inclusion into the epizootic process not only of domestic dogs and cats, which have owners and should be vaccinated, but also homeless and stray dogs and cats that usually are not vaccinated and can move freely over long distances, and in an aggressive form of the disease to attack oncoming animals and people on their way.

This statistic is confirmed by Kornienko et al. (2019), where on the example of the analysis of national data for 2018, it was found that 253 people were bitten by vaccinated stray dogs, and 8788 people $(97.20 \%)$ were affected by unvaccinated stray dogs. If we use the data only for the Vinnytsia Oblast, 98 bites were inflicted by vaccinated stray 


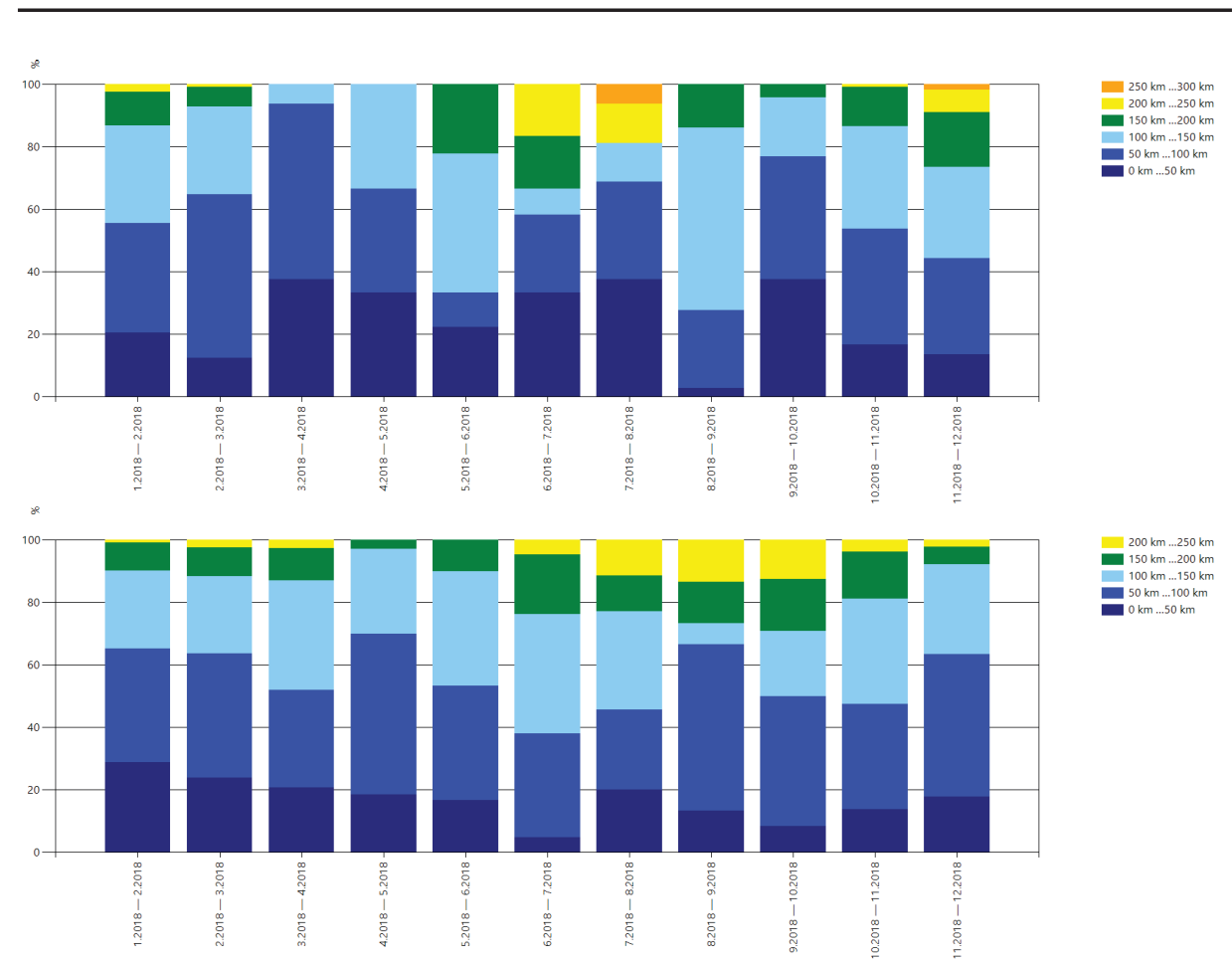

Fig. 5. Dynamics of the distribution of rabies for 2018 on the territory of Vinnytsia Oblast (A - among foxes, B - among domestic carnivores)

dogs and 199 on unvaccinated stray dogs, i.e., twice as many.

It should be noted that even domestic carnivores, which had a host in $80 \%$, were not vaccinated against rabies (Mazur et al., 2017). Also, the high incidence among domestic carnivores, especially cats, indicates a lack of regulation of their number in cities and villages, as well as the lack of a proper number of routine vaccinations among animals of these species (Titarenko, 2019).

When studying the seasonal dynamics, it can be assumed that in winter domestic carnivores transmitted the rabies virus mainly over short distances due to adverse weather conditions that limited movement in general, and in summer this trend reversed and the disease spread to the longer distances due to favourable weather conditions, biological characteristics of cats that are prone to straying (Makovska et al., 2018), and also due to stray animals (Levkivsky et al., 2016).

In order to build the model for modelling dynamics of rabies spread in foxes, 145 confirmed cases of rabies among foxes were studied. The level of dispersion of disease is presented in Table 2.

Thus, we found that rabies spread at a distance of up to $50 \mathrm{~km}$ the most in the spring $(31.01 \%)$ compared to other months, at a distance from 50 to $100 \mathrm{~km}$ in the winter (43.67\%), and at a distance of more than $100 \mathrm{~km}$ - in the summer $(48.38 \%)$, similar to the indicators of domestic carnivores. In general, foxes were sources of rabies within a radius of $50 \mathrm{~km}$ in only $24.33 \%$ of cases and within a radius of $100 \mathrm{~km}$ - in $58.54 \%$ of cases. 


\section{Indicators on the dynamics of the distribution of rabies by domestic carnivores for 2018 in Vinnytsia Oblast}

\begin{tabular}{|c|c|c|c|c|c|c|c|c|}
\hline \multirow{3}{*}{ Month } & \multicolumn{8}{|c|}{ Distance, $\mathrm{km}$} \\
\hline & $<50$ & $\begin{array}{l}\text { Mean } \\
\text { value }\end{array}$ & $50-100$ & $\begin{array}{l}\text { Mean } \\
\text { value }\end{array}$ & $<100$ & $\begin{array}{l}\text { Mean } \\
\text { value }\end{array}$ & $>100$ & $\begin{array}{l}\text { Mean } \\
\text { value }\end{array}$ \\
\hline & \multicolumn{8}{|c|}{ The level of the dispersion of disease, $\%$} \\
\hline January & 28.93 & \multirow{2}{*}{26.45} & 36.36 & \multirow{2}{*}{38.01} & 65.29 & \multirow{2}{*}{64.46} & 34.71 & \multirow{2}{*}{34.53} \\
\hline February & 23.97 & & 39.67 & & 63.64 & & 34.36 & \\
\hline March & 20.78 & \multirow{3}{*}{18.67} & 31.17 & \multirow{3}{*}{39.75} & 51.95 & \multirow{3}{*}{58.43} & 48.05 & \multirow{3}{*}{41.57} \\
\hline April & 18.57 & & 51.43 & & 70.00 & & 30.00 & \\
\hline May & 16.67 & & 36.67 & & 53.34 & & 46.66 & \\
\hline June & 4.76 & \multirow{3}{*}{12.60} & 33.33 & \multirow{3}{*}{37.45} & 38.09 & \multirow{3}{*}{50.15} & 61.91 & \multirow{3}{*}{49.84} \\
\hline July & 20.00 & & 25.71 & & 45.71 & & 54.29 & \\
\hline August & 13.33 & & 53.33 & & 66.66 & & 33.34 & \\
\hline September & 8.33 & \multirow{3}{*}{13.28} & 41.67 & \multirow{3}{*}{40.33} & 50.00 & \multirow{3}{*}{53.61} & 50.00 & \multirow{3}{*}{46.38} \\
\hline October & 13.75 & & 33.75 & & 47.50 & & 52.50 & \\
\hline November & 17.78 & & 45.56 & & 63.34 & & 36.66 & \\
\hline Mean value & 16.98 & & 38.96 & & 55.95 & & 43.86 & \\
\hline
\end{tabular}

2. Indicators on the dynamics of the distribution of rabies by foxes for 2018 in Vinnytsia Oblast

\begin{tabular}{|c|c|c|c|c|c|c|c|c|}
\hline \multirow{3}{*}{ Month } & \multicolumn{8}{|c|}{ Distance, $\mathrm{km}$} \\
\hline & $>50$ & $\begin{array}{l}\text { Mean } \\
\text { value }\end{array}$ & $50-100$ & $\begin{array}{l}\text { Mean } \\
\text { value }\end{array}$ & $>100$ & $\begin{array}{l}\text { Mean } \\
\text { value }\end{array}$ & $<100$ & $\begin{array}{l}\text { Mean } \\
\text { value }\end{array}$ \\
\hline & \multicolumn{8}{|c|}{ The level of dispersion of disease, $\%$} \\
\hline January & 20.62 & \multirow{2}{*}{16.56} & 35.00 & \multirow{2}{*}{43.67} & 55.62 & \multirow{2}{*}{60.23} & 44.38 & \multirow{2}{*}{39.77} \\
\hline February & 12.50 & & 52.34 & & 64.84 & & 35.16 & \\
\hline March & 37.50 & \multirow{3}{*}{31.01} & 56.25 & \multirow{3}{*}{33.56} & 93.75 & \multirow{3}{*}{64.58} & 6.25 & \multirow{3}{*}{35.42} \\
\hline April & 33.33 & & 33.33 & & 66.66 & & 33.34 & \\
\hline May & 22.22 & & 11.11 & & 33.33 & & 66.67 & \\
\hline June & 33.33 & \multirow{3}{*}{24.53} & 25.00 & \multirow{3}{*}{27.08} & 58.33 & \multirow{3}{*}{51.62} & 41.67 & \multirow{3}{*}{48.38} \\
\hline July & 37.50 & & 31.25 & & 68.75 & & 31.25 & \\
\hline August & 2.78 & & 25.00 & & 27.78 & & 72.22 & \\
\hline September & 37.61 & \multirow{3}{*}{22.62} & 39.32 & \multirow{3}{*}{35.68} & 76.93 & \multirow{3}{*}{58.31} & 23.07 & \multirow{3}{*}{41.68} \\
\hline October & 16.64 & & 37.05 & & 53.69 & & 46.31 & \\
\hline November & 13.63 & & 30.69 & & 44.32 & & 55.68 & \\
\hline Mean value & 24.33 & & 34.21 & & 58.54 & & 41.46 & \\
\hline
\end{tabular}


As mentioned above, according to Shcherbak (1982), the fox's migration resources were $10-15 \mathrm{~km}$. Based on this (taking into account the following criteria), a spatial criteria for foci of fox rabies was established, which included the place of detection of a sick or died from rabies animal, including an area within a radius of $10-15 \mathrm{~km}$. However, our results show significant differences. This can be explained by the ecological characteristics of foxes and the high number of fox populations in today's conditions, which increases the prevalence of rabies in wild animals. It is known that the population is affected by the presence or absence of fodder base, which for foxes consists mainly of rodents, and as more land is ploughed for agriculture, the fodder base increases every year, so the prevalence of this species also increases (Brusentsova, 2019). Accordingly, the larger the animal population, the greater the risk of rabies and the greater the area affected.

If we consider the seasonal aspect, then in our results, the vast majority of foxes carried the pathogen for shorter distances in spring, medium in winter, and the longest in summer. The spread of rabies in the winter at distances from 50 to $100 \mathrm{~km}$ might be explained by the need for wild animals to cover long distances in search of prey. Spring and summer trends deserve special consideration, because according to scientists (Golik, 2016; Polupan, 2017) the spring period in foxes is associated with the mating season and they can cover long distances, biting and carrying the causative agent of rabies, and in summer foxes are engaged growing fox cubs and only in the fall disperse throughout the territory. Therefore, this issue requires additional research by both biologists and veterinarians.

\section{Conclusions and future perspectives of the study}

In conclusion, modelling the dynamics of rabies in an area with a high density of rabies cases (Vinnytsia Oblast) for 2018 allowed to obtain new data on the spread of rabies through domestic carnivores. It was determined that at a distance of up to $50 \mathrm{~km}$ rabies is spread mainly in winter, up to $100 \mathrm{~km}$ and more - in summer. In general, domestic carnivores were sources of rabies within a radius of $50 \mathrm{~km}$ in only $16.98 \%$ of cases, and within a radius of $100 \mathrm{~km}-$ in $55.95 \%$ of cases. For foxes, the simulation found that up to $50 \mathrm{~km}$ foxes transmitted rabies the most in the spring months (31.01\%), up to $100 \mathrm{~km}$ - in the winter months $(43.67 \%)$, over $100 \mathrm{~km}-$ also in the summer months (in $48.38 \%$ ).

These results should be taken into account when planning and conducting preventive vaccinations among domestic and wild animals in order to better prevent the spread of rabies, preserve the livestock and humans and eradicate the disease. Prospects for further research will be the forecasting of rabies epizootics in Ukraine.

ACKNOWLEDGEMENTS. The author is grateful to associated professor Nedosekov V.V. (Department of epizootology, microbiology and virology, National University of Life and Environmental Sciences of Ukraine, Kyiv, Ukraine) and to associated professor Soloviov S.O. (Department of Virology, Shupyk National Medical Academy of Postgraduate Education, Kyiv, Ukraine) for assistance in carrying out this work and for careful support.

\section{References}

Achilov, V., \& Nedosekov, V. (2013). Characteristics in rabies epizootic process 
in the Khmelnitsky region. Veterinary Medecine of Ukraine, 06(208):14-17. (in Ukrainian)

Borchering, R. K., Liu, H., Steinhaus, M. C., Gardner, C. L., \& Kuang, Y. (2012). A simple spatiotemporal rabies model for skunk and bat interaction in northeast Texas. Journal of Theoretical Biology, 314:16-22. doi: 10.1016/j.jtbi.2012.08.033

Brusentsova, N. (2019). Home ranges of the red fox, vulpes vulpes (Carnivora, Canidae) and european badger, meles meles (Carnivora, Mustelidae), in oak forests of Slobozhanshchyna, Ukraine. Vestnik Zoologii, 53(1):57-64. doi: 10.2478/vzoo-2019-0006

Cliquet, F., Picard-Meyer, E., \& Robardet, E. (2014). Rabies in Europe: what are the risks? Expert Review of Anti-Infective Therapy, 12(8):905-908. doi: $10.1586 / 14787210.2014 .921570$

Drozhzhe, Z. (2015). Dynamics of the spread of rabies in Ukraine and Europe in 20032013. Veterinary Biotechnology, 26:70-76. (in Ukrainian)

Dzyublyk, I., Soloviov, S., \& Mokhort, H. (2017). Features of rotavirus infection epidemic process in Ukraine and development of its mathematical model. Profilaktychna Medytsyna, 1-2(28):17-28.

Elmore, S. A., Chipman, R. B., Slate, D., Huyvaert, K. P., VerCauteren, K. C., \& Gilbert, A. T. (2017). Management and modeling approaches for controlling raccoon rabies: The road to elimination. PLOS Neglected Tropical Diseases, 11(3), e0005249. doi: 10.1371/journal.pntd.0005249

Golik, M. (2016). The role of the red fox in epizootics of rabies on the territory of Chernihiv oblast. Veterinary Biotechnology, 29: 84-92. (in Ukrainian)

Golik, M., Polupan, I., \& Nedosekov, V. (2018). Forecasting of epizootic of rabies in the Chernihiv oblast on the basis of geoinformation analysis. Scientific reports of NULES of Ukraine, 6(76). doi: 10.31548/dopovidi2018.06.025 (in Ukrainian).
Gulyukin, A., Smolyaninov, Y., \& Shabeykin, A. (2016). The economic damage caused by rabies of agricultural animals in Russia. 8:34-38. doi: 10.18551/rjoas.2016-08.06

Kornienko, L. E., Moroz, O. A., Mezhensky, A. O., Skorokhod, S. V., Datsenko, R. A., Karpulenko, M. S. \& Pishchanskyi, O. V. (2019). Epizootological and epidemiological aspects for rabies in Ukraine for the period from 1999 to 2018. Veterinary science, technologies of animal husbandry and nature management, 3:90-109. doi: 10.31890/vttp.2019.03.14 (in Ukrainian)

Kurtyak, B. (2017). Risks manifestations of rabies can be minimized. Veterinary Medecine, 103:49-52. (in Ukrainian)

Levkivsky, D. M., Levkivska, N. D., Storchak, Y., \& Gutyj, B. V. (2016). Epizootological monitoring of animal rabies in the Lviv region for 2014-2016, the analysis of rabies events. Scientific Messenger of LNU of Veterinary Medicine and Biotechnologies, 18(3(71)):50-53. doi: $10.15421 /$ nvlvet7111 (in Ukrainian)

Makovska, I. F. (2020). New approaches to the analysis on epizootic situation of rabies in Ukraine. The Animal Biology, 22(1):3135. doi: 10.15407/animbiol22.01.031 (in Ukrainian)

Makovska, I. F., Nedosekov, V. V., \& Kornienko, L. E. (2020). Retrospective study of rabies epidemiology in Ukraine (1950-2019). Theoretical and Applied Veterinary Medicine, 8(1):36-49. doi: 10.32819/2020.81007

Makovska, I. F., Nedosekov, V. V., Polupan, I. M., \& Latmanizova, T. S. (2018). Distribution trend rabies in cats in Ukraine. Scientific Messenger of LNU of Veterinary Medicine and Biotechnologies, 20(92):18-23. doi: $10.32718 /$ nvlvet9204 (in Ukrainian)

Mazur, M., Mazur, N., \& Polupan, I. (2017). Видова характеристика епізоотії сказу в Україні за 2011-2016 рр. Scientific Messenger of LNU of Veterinary Medicine and Biotechnologies, 19(73):159-162. doi: 10.15421/nvlvet7333 (in Ukrainian) 
Müller, T., \& Freuling, C. M. (2020). Rabies in terrestrial animals. In Rabies (pp. 195-230). Elsevier. doi: 10.1016/B978-0-12-8187050.00006-6

Perotskaya, L. (2011). Some peculiarities of rabies epizootology of animals in the south of Ukraine. 4(50):353-355. (in Ukrainian)

Polupan, I., Bezymennyi, M., Gibaliuk, Y., Drozhzhe, Z., Rudoi, O., Ukhovskyi, V. ... De Nardi, M. (2019). An analysis of rabies incidence and its geographic spread in the buffer area among orally vaccinated wildlife in Ukraine from 2012 to 2016 . Frontiers in Veterinary Science, 6(September):1-13. doi: 10.3389/fvets.2019.00290

Polupan, I. M. (2017). Antropurgisation of rabies in Ukraine. Ukrainian journal of veterinary sciences, 182-188. (in Ukrainian)

Rattanavipapong, W., Thavorncharoensap, M., Youngkong, S., Genuino, A. J., Anothaisintawee, T., Chaikledkaew, U., \& Meeyai, A. (2019). The impact of transmission dynamics of rabies control: Systematic review. Vaccine, 37:154-165. doi: 10.1016/j.vaccine.2018.11.035

Rebenko, H., Nechiporenko, O. Ponomarenko, V., Mucienko, Y., Fotin, A., Storchak, Y., \& Bakanova, O. (2019). Decreasing of the risk of zoonoses by solving the problem with stray dogs. Bulletin of Sumy National Agrarian University. The Series: Veterinary Medicine, 8(1-2(44-45)):42-49. doi: 10.32845/ bsnau.vet.2019.1-2.6 (in Ukrainian)
Robardet, E., Bosnjak, D., Englund, L., Demetriou, P., Rosado Martín, P., \& Cliquet, F. (2019). Zero endemic cases of wildlife rabies (classical Rabies Virus, RABV) in the European union by 2020: An achievable goal. Tropical medicine and infectious disease, 4(4), 124. doi: 10.3390/tropicalmed4040124

Shcherbak, Yu. N. (1982). Epidemiologiya beshenstva prirodnogo tipa [Epidemiology of natural rabies]. (Doctor's theses). Kyiv. (in Russian)

Sterner, R. T., \& Smith, G. C. (2006). Modelling wildlife rabies: transmission, economics, and conservation. Biological conservation, 131(2), 163-179.

Titarenko, E. V. (2019). Analisis of the epizootic situation on animals rabies in Poltava region. Veterinary Science, Technologies of Animal Husbandry and Nature Management, 8346(3):4-10. doi: 10.31890/ vttp.2019.03.01 (in Ukrainian)

Tkachenko, O., Glebenyk, V., \& Korolenko, L. (2014). Epidemiological monitoring of rabies in the Dnepropetrovsk region. Scientific Technical Bulletin of Biosafety, 2(1):123128. (in Ukrainian)

Yarchuk, B. M., Dovhal, O. V., \& Tyrsin, R. V. (2015). Epizootychna sytuatsiia ta epizootolohichni osoblyvosti zi skazu tvaryn na terytorii Bilotserkivskoho raionu [Epizootic situation and epizootological features of animal rabies in the Bila Tserkva district]. Naukovyi Visnyk Veterynarnoi Medytsyny, 1:63-67. (in Ukrainian)

\section{I. Ф. МаКОВСЬКа (2020). МОДЕЛЮВАННЯ ДИНАМІКИ ПОШИРЕННЯ}

СКАЗУ В УКРАїHI Ukrainian Journal of Veterinary Sciences, 11(3): 33-45, https://doi.org/10.31548/ujvs2020.03.004

Анотація. Завдяки турботі про охорону здоров'я тварин та людей постійно зростають зусилля щодо розроблення математичних та обчислювальних моделей для прогнозування просторової та часової динаміки інфекційних хвороб, у тому числі і сказу. Тому, нашою метою було провести моделювання динаміки поширення сказу лисицями, собаками та котами на прикладі Вінницької області в період із 2012 до 2018 років. Для дослідження та аналізу динамічного поширення сказу в часі та просторі було розроблено інформачійно-аналітичну технологію, 
яка грунтується на основі ретроспективних даних зареєстрованих випадків сказу. Параметр передачі сказу був визначений із використанням офічійних епізоотологічних даних з обласної лабораторії ветеринарної медицини та обласного відділення Держпродспоживслужби України. Виявлено, що сказ серед котів та собак поширювався на відстань до 50 км найбільше (26,45\%) у зимовий період, від 50 до 100 км - в осінній період (40,33\%), понад 100 км - у літній період (49,84\%). Загалом, домашні м'ясоїдні були джерелами сказу в радіусі 50 км лише в 16,98\% випадків, а в радіусі 100 км - уже в 55,95\% випадків. Лисиці були джерелами сказу в радіусі 50 км лише у 24,33\% випадків, а в радіусі 100 км - уже в 58,54 \% випадків. Водночас, найбільше поширення сказу серед лисиць на відстань до 50 км спостерігалось у весняний період (31,01\%), від 50 до 100 км - у зимовий період (43,67\%), понад 100 км -у літній період (48,38\%). Отримані нові дані будуть корисними під час планування та проведення профілактичних антирабічних заходів. У подальшому планується провести моделювання в розрізі всіх областей та створення прогнозів поширення сказу територією України.

Ключові слова: сказ тварин, моделювання поширення сказу, лисичі, домашні м'ясоїдні, інформаційно-аналітичні технології 